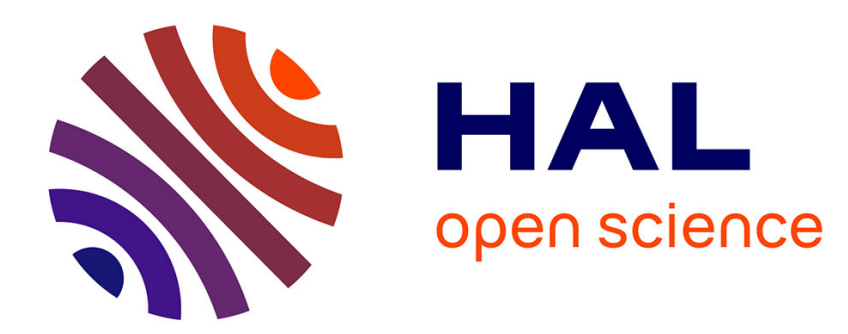

\title{
Computer says no: technology and accountability in policing traffic stops
}

Clare Kinsella, John Mcgarry

\section{To cite this version:}

Clare Kinsella, John Mcgarry. Computer says no: technology and accountability in policing traffic stops. Crime, Law and Social Change, 2011, 55 (2-3), pp.167-184. 10.1007/s10611-011-9277-6 . hal00668055

\section{HAL Id: hal-00668055 https://hal.science/hal-00668055}

Submitted on 9 Feb 2012

HAL is a multi-disciplinary open access archive for the deposit and dissemination of scientific research documents, whether they are published or not. The documents may come from teaching and research institutions in France or abroad, or from public or private research centers.
L'archive ouverte pluridisciplinaire HAL, est destinée au dépôt et à la diffusion de documents scientifiques de niveau recherche, publiés ou non, émanant des établissements d'enseignement et de recherche français ou étrangers, des laboratoires publics ou privés. 


\title{
Computer Says No: Technology and Accountability in Policing Traffic Stops
}

\section{Clare Kinsella and John McGarry*}

\begin{abstract}
The Road Traffic Act 1988 gives police in the United Kingdom the power to seize motor vehicles which they have reasonable grounds for believing are being driven without a valid driver's licence or motor insurance. Drivers may then have to pay a fee to have their vehicles returned. When exercising this power of seizure, the police may rely on information contained on the Police National Computer (PNC) which is linked to the National Insurance Database (NID). Whilst these databases are undoubtedly invaluable in this endeavour, they are not always accurate, and incidents have occurred whereby motorists who are in fact driving with valid insurance have had their vehicles seized and retained.
\end{abstract}

Focusing on the case of Lisa, whose vehicle was wrongly impounded by Merseyside Police in 2007, and other cases, we explore the legitimacy and legality of such activity. We question both the discretionary power of the police in taking such action, and the validity of their (over) reliance on technology. We posit that the taking of money in cases such as Lisa's is evidence of the turn within public policing towards marketisation, and consider the capacity for harm to innocent individuals and the implications for justice and fairness. Ultimately, we contend that police accountability is compromised and that a new approach is required. We close the piece with some recommendations for improved police practice.

\section{Introduction}

In 2005, in the United Kingdom, the Road Traffic Act 1988 (RTA) was amended to give police the power to seize motor vehicles where they have reasonable grounds for believing that the vehicles are being driven without motor insurance or a valid driving licence [40; s.152]. ${ }^{1}$ The police appear to be making vigorous use of this new power. The Motor Insurers' Bureau claims that the police are seizing 500 uninsured vehicles per day [29]. It is likely that a similarly substantial number of vehicles are being seized because the police believe they are being driven without a driver's licence. When making such seizures, the police often use information contained on the Police National Computer (PNC). Once seized, the owner of a vehicle may have to pay a fee to have it released.

\footnotetext{
We would like to thank Julie Davies and Adam Pendlebury for their helpful comments on earlier drafts of this chapter, and Vicky Conway and Dermot Walsh for their excellent editorial guidance. Any errors remain our own. Most importantly, we are grateful to Lisa for discussing her experiences with us and allowing us to use them here.

${ }^{1}$ It should be noted that while in some countries drivers are required by law to display a valid insurance disc in their vehicle no such display requirement exists in the UK under the Road Traffic Act. Drivers must be able to produce evidence of insurance upon request but there can be a delay in the production of this evidence.
} 
The Act therefore gives the police a considerable amount of discretionary power, the exercise of which may adversely affect innocent drivers. As we shall see, there is evidence that a significant number of seized vehicles are subsequently found to have been lawfully driven. In such cases, the innocent driver may experience distress, anxiety and inconvenience.

We examine various aspects of this discretionary power. We draw on the experience of Lisa, who had her car seized under the RTA, in Liverpool, and consider other cases similar to hers. Lisa's car was seized by officers from Merseyside Police in November 2007 as being driven without insurance; it was, in fact, insured. She recounted the facts to us in a recorded interview on $4^{\text {th }}$ November 2009 . We examine the legality and legitimacy of the seizure power. In particular, we look at the grounds on which a vehicle may be seized, including the propriety of relying on, and the weight that should be attached to, information on the PNC. We also consider the legitimacy of charging owners to reclaim their property. Throughout the piece we reflect on the complex dynamics of discretion, accountability and technology, within the context of shifts from public to private policing, post-crime to pre-crime policing, and the infiltration of "low" policing by "high" policing. We explore the potential implications for trust, fairness and harm. We conclude by suggesting that existing accountability structures are not adequate for overseeing policing of this nature and make some recommendations for improved practice.

\section{Lisa's Case}

Lisa was stopped by the police while driving with her brother to collect her son from nursery one weekday afternoon, at about 1pm, in November 2007. She encountered a police roadside operation which seemed to be checking whether cars were being driven lawfully - with a valid driving licence and motor insurance. The police appeared to be stopping cars at random and an officer indicated to Lisa that she should stop.

The officer checked Lisa's details via police radio and said that no insurance entry for her car could be found. Lisa replied that the car was insured through DNA insurance. The officer laughed and stated that she must be mistaken, that DNA refers to a police test. In fact, he joked with one of his colleagues that she had misunderstood and 
thought that DNA could be an insurance broker. Lisa responded that she realised that DNA was the name of a test used by the police, but reiterated that it was also the name of her broker. The officer said that they could find no record of it and that they would have to seize her car.

Lisa told the officer that she could get her insurance certificate to prove that the car was insured and asked for it not to be removed in her absence. She was told that the car would be removed when there were a number of cars ready to be transported away. That is, the car would be kept for a short time but the police would not specifically hold it there.

It was about an hour before Lisa was able to return with proof of her insurance. She immediately noticed that her car had been removed. When the officer with whom she had previously dealt saw her, his first word was 'shit'. Lisa said that the look on his face indicated that he realised a mistake had been made. She asked where her car was and he called his sergeant over who was, in her words, 'very strict, very stern'. The sergeant explained that, as far as they had known she was driving without insurance and she had no proof to demonstrate otherwise. He said that they had kept her car for a short while but restated that once a certain number of vehicles have been seized all are removed.

Lisa was instructed to present the proof of her insurance at a police station across the city, rather than the one closest to the scene. On arriving, after a long journey through school run traffic, she was kept waiting for about 20 minutes. When her insurance certificate had been confirmed as valid, she asked for the keys to her vehicle but was told that, rather than her car being at the station as she had been given to believe, it was being held at a car impound, about two miles from where she was first stopped. Further, she was informed that the impound had closed. This meant that she could not retrieve the car until the next day and so had to pay an overnight fee on top of the impound fee. 
In total, Lisa had to pay $£ 117$ to have her car released. ${ }^{2}$ In interview she told us that as a single mother and a student this was a substantial amount of money to her and, in fact, she had to borrow the money from her father to pay the release fee.

Her father retrieved the car on her behalf the following morning. On doing so he found that it had a large yellow sticker across the windscreen, 'which was an absolute swine to get off'. The notice was headed by Merseyside Police's logo and stated in large black uppercase letters: 'SEIZED BY POLICE DRIVEN WITHOUT INSURANCE'?

\section{Wider Context}

Lisa's car was probably seized as part of Operation Tango. This is the 'total war declared by Merseyside Police on anti social (sic) and irresponsible drivers who use our roads'; its aim is that those who 'use a vehicle in a crminal (sic) and anti social manner ... will be caught, [their] vehicle ... seized and [they] will be prosecuted' [8].

Since hearing of this incident, we have become aware of other instances where insured drivers have had their cars seized. Two cases are particularly noteworthy. In March 2008, Cumbria police stopped Stephen Farndon's car on the M6 motorway because it was shown on the National Insurance Database (NID) as being without insurance. It appears that Mr Farndon's insurers had failed to register the details of his policy on the Database. Newspaper reports state that the police seized the vehicle and then stopped the traffic on a motorway slip road so that Mr Farndon, his wife, and two children could walk off the motorway carrying their 12 month old grandson [12]. Similarly, in January 2008 Stephen Booth had his car seized after police could not find his insurance details on the NID, even though he had renewed his insurance four days earlier. He refused to pay the $£ 105$ fee to recover his car, an amount of money that rose by $£ 12$ for every day that the car was held. The car was crushed fourteen days later [3].

As we noted in the introduction, the Motor Insurers' Bureau claims that the police are using the NID to seize 500 uninsured vehicles per day throughout the UK. This

\footnotetext{
${ }^{2} £ 105$ for removal of the vehicle and $£ 12$ for its retention for each 24 hour period, or part thereof. These charges are now $£ 150$ and $£ 20$ respectively [37].

${ }^{3}$ The legality of this is explored elsewhere [25].
} 
equates to 182,500 vehicles per year. In addition to these, the police may be seizing a similarly high number of vehicles where they believe they are being driven without a valid driver's licence. ${ }^{4}$

In reply to a number of Freedom of Information requests, many police forces informed us that they do not collate information on how many seized vehicles are subsequently discovered to have been driven lawfully. Some were, however, able to give us some indicative figures. ${ }^{5}$ Leicestershire Constabulary estimate that between $2 \%$ and $4 \%$ of the total number of vehicles seized are later found to be lawfully driven. ${ }^{6}$ Figures supplied by Norfolk Constabulary indicate that, for them, it is about $2.5 \%{ }^{7}$ Cheshire Constabulary state that in 2009 they paid for the recovery of just under $1 \%$ of vehicles seized. ${ }^{8}$ This does not represent the full figure of vehicles that have been seized when lawfully driven as the force does not pay where the seizures were the result of errors made by the DVLA or insurance companies. Figures from other forces indicate that refunds have been made in $0.089 \%$ to $0.584 \%$ of cases $^{9}-$ though, again, this only accounts for a portion of vehicles seized but later found to be driven lawfully as refunds are not made in all cases. Though varied and incomplete, these figures suggest that a significant number of vehicles seized may, in fact, be lawfully driven.

\section{Stopping and Seizing Vehicles}

Section 163 of the RTA obliges drivers to stop their vehicles when required to do so by a uniformed officer. It is reasonably settled law that, under this provision, an officer does not need any grounds to stop a vehicle provided she does not act 'capriciously or in bad faith, [and] provided there is no malpractice or oppression or

\footnotetext{
${ }^{4}$ There does not seem to be any readily available data on how many vehicles are seized as being driven without a valid driver's licence.

${ }^{5}$ Many replies emphasised that different police forces capture and record the data in different ways, therefore this information should not be used to make comparisons between forces.

${ }^{6}$ Freedom of Information (FOI) reply, 25 February 2010.

${ }^{7}$ FOI reply, 30 April 2010.

${ }^{8}$ FOI reply, 12 March 2010.

${ }^{9}$ Bedfordshire $=0.126 \%$ (FOI reply, 1 March 2010); Kent $=0.2 \%$ (10 March 2010); Lancashire $=$ $0.263 \%$ (5 March 2010); Merseyside = 0.331\% (22 February 2010); Metropolitan Police $=0.584 \%(18$ March 2010) Nottinghamshire $=0.089 \%$ (24 February 2010); South Yorkshire $=0.168 \%(12$ March 2010).
} 
opprobrious behaviour.' ${ }^{10}$ This is a power which also exists in parallel at common law. ${ }^{11}$

Once stopped, a driver may also be required to produce the following documents for examination: the driving licence and its counter part [36; s.164(1)]; the relevant certificate of motor insurance or other evidence that the vehicle is not being driven without third party cover; and an MOT test certificate [36; s.165]. A failure to produce these documents when required to do so is an offence [36; ss. 164(6) and 165(3)]. It is a defence, though, if the driver produces the required documents at a police station within seven days [36; ss. 164(8) and 165(4)].

If a driver cannot produce their licence or insurance certificate, and a uniformed officer has reasonable grounds for believing that the vehicle is being driven without licence or insurance, she may seize it [36; s.165A insert by $40 ; \mathrm{s.152}] .^{12}$ A central question when assessing the legitimacy and legality of a seizure is whether the officer had the necessary reasonable grounds for belief.

Reasonableness is not defined in the legislation but case law indicates that it is an objective test ${ }^{13}$ which is ultimately a question for the court: the court must be satisfied that the knowledge and perceptions of the officer at the time were sufficient to give rise to reasonable grounds and this assessment is not to be made with the benefit of hindsight. ${ }^{14}$ The threshold for reasonable belief is higher than that for reasonable suspicion, ${ }^{15}$ yet, like reasonable suspicion, stereotypical images are not enough to give rise to reasonable belief. ${ }^{16}$ What is sufficient will vary from case to case but the officer is entitled to take into account all available information. ${ }^{17}$

\footnotetext{
${ }^{10} R$ (Beckett) v Aylesbury County Court [2004] EWHC 100, [13].

${ }^{11} R$ (Beckett) v Aylesbury County Court [2004] EWHC 100 and Chief Constable of Gwent v Dash [1986] RTR 41 (QBD) 46.

${ }^{12}$ During the passage of the Bill, the human rights organisation JUSTICE questioned whether this provision might infringe the right to peaceful enjoyment of one's possessions protected by Article 1 of the First Protocol to the European Convention of Human Rights. They also state that the Article 6 right to have one's civil rights determined by a fair and impartial tribunal is also engaged, see Ireland [16; para 78].

${ }^{13}$ Bucknell v DPP [2006] EWHC 1888, [9].

${ }^{14}$ Redmond-Bate v DPP [2000] HRLR 249 (QBD) [6].

15 'Suspicion is a state of mind well short of belief ...', Hughes LJ in Buckley \& Ors $v$ The Chief Officer of Thames Valley Police [2009] EWCA Civ 356, [7].

${ }^{16}$ DPP v L [2005] EWHC 1229, [30].

${ }^{17} D P P$ v L [2005] EWHC 1229, [29].
} 
As we see in our example, factors on which the police may rely to seize a vehicle include the absence of the driver's insurance details from the database; that the driver cannot immediately provide proof of insurance; and the officer's failure to recognise the name of the insurance company. ${ }^{18} \mathrm{We}$ will examine the sufficiency of these in turn.

\section{Prioritising Technology?}

The PNC will often be relied on when searching for a driver's insurance details. This is linked to the NID. Merseyside Police's current Policy and Procedure on the Seizure and Retention of Vehicles states that the absence of a motorist's details from the database can only give rise to reasonable suspicion; reasonable belief requires more:

The PNC indicating either insurance 'not held' or 'unlicensed driver' is only sufficient to provide suspicion. The officer must establish further grounds to support a reasonable belief based on their own personal knowledge, other supporting intelligence and information provided by the driver. These further grounds must be recorded in the officers (sic) pocket notebook (emphasis added). $[26]^{19}$

This is consistent with the view of the Motor Insurers' Bureau, which manages the NID. They state that the police cannot seize a vehicle simply because it is absent from the Database; rather, the Database is an aid to help form the reasonable belief that a car is being driven uninsured [28].

Providers of insurance are obliged to supply the details of all insured vehicles to the Database. ${ }^{20}$ Yet, the Database should not be taken as being necessarily comprehensive or up-to-date, this is for at least two reasons. First, information is loaded onto the Database mainly by insurance companies directly [30]. There is, then, room for error; companies may fail to load the data or may do so incorrectly. A number of police

\footnotetext{
${ }^{18}$ More grounds may become apparent as police practice develops and other cases emerge but these seem to be the most likely common grounds.

${ }^{19}$ It does not appear as though the preceding policy contains similar advice: The Removal of Vehicles from the Road: Statement of Policy (2006).

${ }^{20}$ Under ss 95(2) and 145(2) RTA, those providing motor insurance must be a member of the Motor Insurers' Bureau which requires its members to enter the details of motor insurance polices on the Database. Also, the Motor Vehicles (Compulsory Insurance) (Information Centre and Compensation Body) Regulations (Number 37) r. 5 obliges insurers to provide this information to the Motor Insurance Information Centre (essentially, the MID) when required to do so.
} 
forces have indicated that this is a main cause of insured vehicles being seized erroneously. ${ }^{21}$ Second, there may be a delay in loading the information onto the database. For privately owned vehicles, information should be entered onto the Database within seven days of the insurance policy starting [27], meaning that the details may be missing from the Database for this period of time. In addition, it is possible that an insurance company may take longer than the rules allow to upload data. It therefore seems appropriate to assume that the absence of the details of a particular motor insurance policy from the Database is not adequate, per se, to give rise to a reasonable belief that a vehicle is uninsured.

This does, though, appear to be the primary deciding factor in many cases. If so, then it suggests that there has been an over-reliance on the Database. It may also be contextualised as a feature of what Zedner calls 'dataveillance', or the surveillance of criminal, or potentially criminal, groups via the collation, storing and sharing of data [43; p.75]. Police use of technological tools of this nature can further be understood as part of a broader and long-standing drive towards developing criminal intelligence. Defined by Brown as 'information which is significant or potentially significant for an enquiry or potential enquiry' [5; p.340], criminal intelligence 'has been embraced as the great law enforcement hope for the future' [5; p.340]. In this sense, individual, "everyday" cases are reflective of the "trickle down" effect from more serious, international crime where the justification seems more obvious' [43; p.75].

The prioritisation of criminal intelligence is a current focus of debate [19], however, Brown contends that a distinction must be drawn between what constitutes information and what constitutes intelligence. Here, information in its raw state only becomes intelligence when it is linked to other information, adding "value" to the information and transforming it into something which can then become the basis of decision making [5; p.336]. We have argued above that reliance on the PNC/NID is not sufficient to give rise to the reasonable grounds of belief necessary to seize a vehicle. Using Brown's analysis, it can also be argued that use of information gleaned from the Database falls short of the benchmark of intelligence which should inform

\footnotetext{
${ }^{21}$ This was given as the primary reason for such errors in FOI by Bedfordshire (1 March 2010), Gloucestershire (5 March 2010), Hampshire (24 February 2010), Kent (10 March 2010), Lancashire (5 march 2010), Leicestershire (25 February 2010), Metropolitan Police (18 March 2010), and Warwickshire (10 March 2010) Constabularies.
} 
the decision to proceed. Moreover, over-reliance on the PNC/NID is, perhaps, reflective of an unhelpful preoccupation and prioritisation of technology within the police service in the execution of their duties.

Undoubtedly, developments in technology have had a continual impact on the delivery of policing in the UK, dating back as far as provision made for forensic science laboratories and wireless depots in the Police Act 1919 [33]. At first sight, it appears that harnessing technological advances serve to enhance the provision of policing;

New technologies promise improved effectiveness and efficiency in policing. Technologies extend the physical capacities of police officers to see, hear, recognise, record, remember, match, verify, analyse and communicate. [9; p.655]

The beneficial aspects of "technological" policing are perhaps best encapsulated, particularly to the lay person, as the "CSI effect":

Perhaps the most prominent current example ... is the TV show CSI (Crime Scene Investigation), focussing on homicide detectives, assisted by creative and incisive technical support staff, using a dazzling array of state-of-the-art technology, combined with hugely powerful databases, to perform scientific analyses of crime scenes and victims to conclusively establish the identity of the killer. [32; p.203]

The "CSI effect" is indicative of the desire for policing to be scientific, as science is seen as neutral, impartial and free from human error [10]. However, whilst proponents of technological policing may be blinded to its drawbacks $[22],{ }^{22}$ others are keen to warn against the potential negative consequences of such developments [31].

Former Chief Constable of Devon and Cornwall, John Alderson, published Policing Freedom over thirty years ago. In it, he argues that the police have become seduced by the brilliance of technology, writing that technology 'has had a profound effect on police methods, public image and reputation, to say nothing of police psychology.' [1; p.41] He further states: 'This seductive power of technology has resulted in a false

\footnotetext{
${ }^{22}$ Although Manning [22] also recognises that technological advances often meet resistance from serving police officers at varying levels who are, for instance, sceptical of their efficacy or mistrustful as to the extent to which they may diminish their role.
} 
assumption that, together with the legal powers, it provides the essence of policing. This is a profound mistake' $[1 ;$ p.41].

Alderson's concerns continue to have resonance, and are perhaps even more of a concern now. The police could easily become over-reliant on technology, in this instance the PNC/NID, viewing it as unquestionable, unfailing, and incapable of being wrong. This is a key problem with police prioritisation of technology: it fails to allow for, or accept the possibility of, technological failure, and officers at a scene may not consider the possibility that the non-appearance of insurance details on the Database could be an error. This may result in an unwillingness to give the driver a reasonable chance to prove that their car was correctly insured, and officers may not take additional action themselves to try to verify drivers' claims. In spite of the wellknown potential problems with technology of this nature, ${ }^{23}$ the pronouncement of the computer is prioritised over the driver's word. The result is that the insured driver, an innocent citizen, may experience harm, ranging from inconvenience to embarrassment, distress, intimidation, public shaming, loss of time, and financial loss.

\section{Insurance: Proof and Disbelief}

We have argued that absence of insurance details from the PNC/NID is not, in itself, sufficient to give rise to the reasonable grounds necessary to enable seizure of a car. Here, we assess whether such reasonable grounds are present when a driver is also unable to produce her insurance certificate at the time she was stopped. That is, whether this additional fact is enough to take the officer from reasonable suspicion to reasonable belief.

Some police forces do seem to assume that this additional fact is sufficient to enable seizure of a vehicle. In reply to a Freedom of Information request, Devon and Cornwall Police state:

\footnotetext{
${ }^{23}$ Whilst there are some undeniable benefits attached to the growth in the use of technology generally, and information technology specifically, by the police (see e.g. Bowling [2] for a positive evaluation of the NYPD's Compstat system), developments in this area cannot wholly be accepted as a good. Manning [22], for example, details the inefficacy of crime mapping as an analytical tool. Similarly, HM Inspectorate of Constabulary (cited in Chan [6]) found that increased use of computerised record systems has not improved accuracy or efficiency in the keeping of records. More broadly, Parenti [32] identifies police adoption of paramilitary style technologies as a gateway to aggressive policing tactics and even brutality.
} 
Officers at the roadside will check the National Motor Insurers (sic) Database and DVLA Database to determine if insurance is held and if the driver is correctly licensed to drive. Should information from the databases indicate either insurance is not held or the driver is not correctly licensed, then the Officer can use his seizure powers under Section 165 (sic) of the Road Traffic Act 1988 unless the driver can provide proof at the roadside that insurance is held or their licence is valid. ${ }^{24}$

Similarly, Gloucester Constabulary state that they have seized vehicles where absence from the Database along with a driver's inability to prove their vehicle was being lawfully driven led officers to believe it was being driven unlawfully. ${ }^{25}$

We question, however, whether an inability to produce one's insurance certificate, or driving licence, at the roadside when asked to do so is an additional factor sufficient to take the officer from reasonable suspicion to reasonable belief. First, s. 165A RTA states that the power to seize a vehicle arises only if the officer has reasonable grounds to believe, say, that it is being driven without insurance and the driver is unable to provide proof of insurance at the roadside; this is clear from section $165 \mathrm{~A}(3)$ which empowers an officer to seize a vehicle if:

(a) a constable in uniform requires, under section 165, a person to produce evidence that a motor vehicle is not or was not being driven in contravention of section 143 [ie: without valid motor insurance],

(b) the person fails to produce such evidence, and

(c) the constable has reasonable grounds for believing that the vehicle is or was being so driven (emphasis added). ${ }^{26}$

Given that reasonable grounds for belief are required in addition to the failure to produce a certificate of insurance, it seems mistaken to conclude that the latter can be a contributing factor in shaping the former.

Further, where police are randomly stopping cars to check whether they are being driven lawfully, it would only be necessary to check the PNC/NID if a driver could not produce evidence of insurance; this check would be unnecessary if the driver had

\footnotetext{
${ }^{24}$ FOI reply, 4 March 2010.

${ }^{25}$ FOI reply, 5 March 2010.

${ }^{26}$ Section $165 \mathrm{~A}(2)$ is similar and relates to reasonable grounds for believing that a vehicle is being driven without a valid driver's licence. Section 165A(4) empowers an officer to seize a vehicle where the vehicle has not stopped when required to do so and the officer believes that it is being driven without insurance or a valid driving licence.
} 
such proof. Thus, if we are correct in assuming that absence from the Database is not in itself sufficient to give rise to reasonable belief, it must be the case that a circumstance that preceded the database being checked (i.e. the driver is unable to provide evidence of insurance) is incapable of making up the shortfall to give rise to belief. $^{27}$

The additional failure to recognise the name of an insurance company is also, perhaps, inadequate to form reasonable belief, at least without further investigation. It may form suspicion, but not belief. Arguably, given the impact of seizure for a driver, the police could and should, take reasonable steps to verify the existence of an insurance company before acting. It is worth noting here that entering 'DNA insurance' into Google, and restricting the search to UK pages, gives over 3,000 results. It may also be asked whether, when a driver claims that they can get proof that their car is being driven with valid insurance, the police should not make every attempt to facilitate this.

\section{Retaining Vehicles}

Once a vehicle has been seized it may be removed and retained. Section 165B RTA empowers the Secretary of State to make regulations authorising this. These may specify the fee that must be paid before a vehicle is released. Importantly, these regulations,

must provide that a person who would otherwise be liable to pay ... will not be liable to pay if -

(a) he was not driving the motor vehicle at the time in question, and

(b) he did not know that the vehicle was being driven at that time, had not consented to its being driven and could not, by the taking of reasonable steps, have prevented it from being driven (emphasis added). ${ }^{28}$

The Home Office explanatory memorandum on the operation of section 165(B) gives the reason for this provision: 'to ensure that no-one is unfairly penalised or deprived

\footnotetext{
${ }^{27}$ Moreover, surely a significant number of drivers do not carry evidence of insurance with them as a matter of course. Thus, the inability to produce such evidence when asked to do so is relatively unremarkable and so should perhaps be considered insufficient to take an officer from reasonable suspicion to reasonable belief.

${ }^{28}$ Section $165 \mathrm{~B}(3)$.
} 
of a vehicle he owns' [14; para 7.4]. Given our research, we question why this is the only exemption required by the legislation.

Police forces may adopt their own reimbursement policy for vehicles incorrectly seized - though neither the RTA nor its attendant regulations oblige them to do so. Some forces reimburse drivers whose vehicle is subsequently proved to be lawfully driven [26; p.7]; others do so only if the seizure was due to their error. ${ }^{29}$ Even where there is a reimbursement policy, innocent drivers will still have to pay to retrieve vehicles - initially at least. Some may feel so demoralized by their experience that they are loath to prolong it in an attempt to have their money returned..$^{30}$ Some may be unable to afford the charge with the result that it will be increased on a daily basis and their vehicle might eventually be destroyed. We question whether there needs to be an exchange of money at all; surely those who can prove that their vehicle was being driven lawfully can simply have it returned.

\section{The Public Police Operating as a Private Entity}

Zedner talks about a shift in emphasis from the idea of a post-crime society, where crime is responded to after it has occurred, to a pre-crime society which draws on risk and security doctrines to go beyond traditional crime prevention tactics [44].

Describing 'a society in which the possibility of forestalling risks competes with and even takes precedence over responding to wrongs done', she highlights developments which are essentially pre-emptive measures to eliminate risk even where none exists [44; p.262]. Further, she notes that the distinction between public and private policing is becoming less clear - in fact, she equates post-crime activity with the functions of the public police and pre-crime with the private, "for profit" domain. Similarly, Loader notes the trend developing since the early 1980s within the public police towards marketisation - the police becoming more influenced by market principles, and in some cases charging for particular services [20 and 43]. That charges of over $£ 100$ can be incurred by those thought to be driving uninsured leads us to consider the possibility that the police service, and/or associated organisations, are profiting financially from traffic stops of this nature, above the actual administrative costs which the stop and retention of the vehicle may reasonably incur.

\footnotetext{
${ }^{29}$ This is the case with Hampshire Constabulary: FOI reply, 24 February 2010.

${ }^{30}$ Lisa indicated that this was the case with her.
} 
We raise this for three important reasons. First, the applicable regulations [37] do not make clear how the current figures of $£ 150$ to cover the cost of removal, and $£ 20$ per day to cover the cost of retaining, the vehicle have been calculated. Further, we have been unable to uncover a rationale for how the Department of Transport has arrived at these figures in terms of what the charges are specifically designed to cover, and how they can be broken down into exact component figures. This leads us to question whether the figures have been established in an arbitrary manner.

Second, given that vehicles seized by the police are removed by car transporter, and then retained at an impound site, we are concerned that, for some forces at least, contractual financial relationships are being forged with private organisations who will charge for the use of their facilities. If this is the case, it would constitute a clear example of both the blurring of the lines between public and private policing [17 and $42]$ and the burgeoning private security industry [18].

Third, and perhaps most pertinent, we question why charges are made for the seizure and removal of vehicles at all. While driving without insurance is a criminal offence, there seems to be no reason why those whom the police believe to have committed the offence should be charged for the processing of their case. This approach is not taken for those charged with equivalent or more serious motoring offences such as driving while under the influence of alcohol or causing death by dangerous driving; costs pertaining to these offences are covered within policing and other criminal justice agency budgets and thus are ultimately paid for by the taxpayer. Meanwhile, it is commonplace for fixed penalty notices to be issued for minor motoring offences such as exceeding the speed limit [36; s. 51 and schedule 3]. We question why a third approach - charging for the seizure and retention of vehicles - is used for those driving without insurance or driver's licence (or those erroneously thought to be doing so).

The idea that the police may stand to gain financially is unpalatable in cases where vehicles are being driven unlawfully, and against the spirit and ethos of a public police service. Where this is occurring when the driver is insured, the police may be 
vulnerable to speculation that they are operating on a "for profit" basis, regardless of the accuracy (or inaccuracy) of their evidence.

Reiner contends that previous models of police accountability have been usurped by a 'calculative and contractual' model [34]. In the UK, in the wake of the Sheehy Report [37], and reflecting the post-1979 broader move towards privatisation and marketisation, police accountability is both administered and measured via market disciplines - the setting and meeting of targets, audits, and performance management. Loader [20] contends that this drift towards consumerism is wholly contrary to traditional notions of democratic policing, in that the public who access the services of the police are increasingly responded to as customers exercising their purchasing power rather than citizens exercising their democratic right to secure access to (limited) police resources. The implications for police accountability are clear - if the public are encouraged to develop a sense that any solution to crime "problems" can be bought, it is possible that problems regarding the function of the police will be viewed as problems that can be overcome by buying "better" services rather than problems to be addressed via recognised formal accountability structures [17]. In short, the movement towards private activity within the public police is indicative of the dilution of the 'sacred' representation of the police as 'symbols of law, order and nation' [20; p.387] who must be held accountable on more counts than the value for money they offer.

In any event, drawing on Zedner's work it is clear that these encounters are indicative of strategies of pre-emption which permeate police activity at every level, ranging from the micro (for example, the management of traffic offences) to the macro (for example, anti-terrorist activity). We submit that current trends towards pre-emption which leave behind established notions of standard crime prevention, blended with the speedy and steady growth of the private security industry, are particularly worrying. Johnston [17] contends that the period between approximately 1800 and approximately 1970, where public policing was the dominant form of policing and viewed as the most appropriate, is an aberration; the inevitable intention of policing within capitalist societies is to be a wholly commercial enterprise, and shifts towards more private forms of policing evident throughout the last 30 years are indicative of policing returning to its 'natural' state. Zedner's claim that 'private security is by 
nature entrepreneurial and springs up where opportunity arises' indicates that organisations seeking to exploit the current climate are not beyond creating such openings where none actually exist [43; p.105]; it seems to us that "inventing" crime before it actually occurs, when it may never occur, opens up a whole new range of pre-emptive and profitable opportunities.

\section{Fairness, Harm and Accountability}

Drawing on discussions surrounding developments in criminal justice as a function of the risk doctrines associated with late modernity, Hudson contends that crime prevention has undergone a significant shift in emphasis from risk management to risk control [15]. Identifying risk management as a constant feature of policing, she asserts that the new trend is that strategies developed to this end now cross the line of acceptability in terms of both proportion and target, in an attempt to control, rather than simply manage, the potential for criminal activity. Further, she contends that the focus on groups of actual or potential offenders, rather than individuals within a specific context, is reflective of the 'turn that seems to have taken place from justice to vengeance, from due process to gloves-off crime control' [15; p.45]. For Hudson, the result is that

The new systems of risk control violate some of the fundamental tenets of due process. The principles of no punishment without conviction, and proportionality of punishment to harm done, are set aside by the new technologies of risk. [15; p.67]

Just as core principles of criminal justice have undergone a significant paradigm shift, one of the central theoretical principles of policing - that the police should be accountable to the people - has also evolved. Brodeur [4] discusses "high" policing, essentially state policing on a macro level predominantly geared towards maintaining national security, and identifies this as conceptually distinct from "low" policing, the regular, "everyday" police work of the street. However, he demonstrates that the core principles of high policing - heightened importance of intelligence, conflation of powers which should be separate, focus on national security, and technological surveillance - are increasingly infiltrating aspects of low policing. Whilst high policing activity is held accountable via political hierarchies, low policing is thought to be accountable to the judiciary. 
Similarly, Chan [7] notes that the conceptual basis of police accountability, rather than prioritising the needs of the public and the rule of law, now revolves around pragmatism, managerialism, and risk management. She demonstrates the failings of such approaches to police accountability, and the public perception that the traditional purpose and spirit of police accountability should be restored. Summing up the central problem of this shift, she states that: 'The new accountability's project of managing the risk of official misconduct is continually frustrated by evidence of its failure and the attendant swing back to punitive control strategies' [7; p.266].

It is against this contextual backdrop that we need to consider Lisa's experience. Given that the police appear to have relied mainly, or perhaps entirely, on the NID, an 'electronic technique' symptomatic of the move towards 'following people's movements through and across computerised databases' [15; p.45], and given that, without 'due process', the net result has been a financial penalty, it can be argued that the police have effectively acted as judge and jury themselves. On the grounds of faulty evidence, they have arguably concluded that Lisa was guilty of driving without insurance and handed down the punishment of what effectively is a fine.

In short, the police can be understood as going beyond their commonly recognised boundaries and treading on the toes of the courts, in terms of considering evidence, establishing guilt, and handing down punishment, a practice which has potential implications for the principle of due process and the wider principles of justice upon which the whole criminal justice system should be based. As Tugendhat J stated in a defamation case brought against the police: 'The imposition of sanctions is a matter for the courts, after conviction, and never for the police. ${ }^{31}$

Further, because the police are acting outside their established role and function [36], it is questionable whether they can be sufficiently held to account, and whether their actions could be challenged by the public. The system of checks and balances to which they have traditionally been subjected may be less able to deal with a police service acting outside their acknowledged remit. More specifically, the danger is that when the police are responsible for determining guilt and punishment, the oversight

\footnotetext{
${ }^{31}$ Wood v Chief Constable of the West Midlands Police [2003] EWHC 297, [50].
} 
role played by the courts, and to some extent the Crown Prosecution Service, is absent. In any event, it is further evidence of the permeation of everyday, "low" policing by the principles of "high" policing, whereby "the conflation of legal, judicial and executive power is one of [its] defining aspects' [4; p.32].

This distortion of the police's function in terms of criminal justice has had a significant and long lasting effect on Lisa. In total, she has incurred a financial loss as a result of these events totalling $£ 117$, a loss which she felt unable to recoup because she was so distressed by the episode. She also felt 'very intimidated' by the situation and 'didn't want to start challenging the police' by seeking reimbursement.

For Lisa, this was compounded by two significant features of the way she was responded to by officers at the scene. First, her sensation that the officers she was stopped by thought she was 'stupid', treating her in a dismissive and patronising way because they assumed that she was mistaken in thinking that DNA could be the name of an insurance broker. Second, her sensation that she had been responded to in a gendered fashion - she felt that the officers might have treated her differently, to use her words, 'had it been a male' that they were dealing with. She also recalls the male officers in question speaking to her brother in a way which was wholly different than the way with which she was dealt. In short, Lisa feels that the officers' confusion over the existence of an insurance company named DNA, coupled with their reactions to her as a woman driver, resulted in them treating her in a dismissive and condescending way.

This is illustrative of the paradoxical relationship between the use of technology in policing and the role of individual officer discretion. On the one hand, officers may feel compelled to seize vehicles because the computer has effectively told them to do so. Yet, at the same time, officers are arguably able to employ their discretion as to their conduct once a driver has been stopped, and the decisions they subsequently take - for example, whether or not to seek further information as to the existence or nonexistence of an insurance company. Given the array of research on the problematic nature of individual police discretion and the ways it can be influenced by both personal beliefs and "cop culture" [39, 23, 40 and 6], it is entirely possible that officers may make discriminatory decisions about how to proceed in a particular case, 
decisions which they can absolve themselves of by deflecting "blame" on to the computer. In other words, officers can still operate their discretion even when reliance on the database arguably removes it.

We referred above to the case of Stephen Farndon who had his car seized on the motorway resulting in him walking along a motorway slip road with his family; he said, in reference to the way he was treated: 'You are perceived guilty by the side of the road before you get a chance to prove you are innocent' [12]. As we have seen throughout this piece, and through cases such as Lisa's and Mr Farndon's, the potential for harm in this area, in terms of misadministration of justice, is considerable.

Perhaps the more long-term harm however is that Lisa now reports having feelings of mistrust towards the police, and a belief that the police have exercised their power in her case both erroneously and in a manner which goes beyond the principle of "reasonableness". It is not uncommon for people to report a change in attitude towards, and lack of confidence in, the police after a negative encounter $[11,38,12]$. The cynicism, wariness and even opposition that can develop towards the police after such an experience is perhaps however reminiscent of Alderson's warning that 'The police have to balance the desire and need to increase their efficiency with the genuine fear of the public against over-mighty officialdom' [1; p.106]. Arguably, calls by Alderson to be mindful of the 'human side' of policing continue in some cases to be ignored, an area of neglect which, Tyler [41] notes, further erodes the respect, acceptance and good will of the public required for the police to be seen as functioning legitimately, fairly, and with the consent of the people.

Finally, we question whether Lisa, and others like her, have been treated fairly. We noted earlier the Home Office claim that the regulations governing the retention of vehicles seized seek to 'ensure that no-one is unfairly penalised or deprived of a vehicle he owns' (emphasis added) [26]. Similarly, the Police (Conduct) Regulations 2008 state: 'Police officers act with fairness and impartiality' (emphasis added) ${ }^{32}$ Likewise, Merseyside Police promise: 'We will treat everyone we deal with fairly,

\footnotetext{
${ }^{32}$ Schedule 1, paragraph 1 .The previous regulations similarly stated: 'Police officers have a particular responsibility to act with fairness and impartiality in all their dealings with the public and their colleagues': Police (Conduct) Regulation 2004, schedule 1, paragraph 1.
} 
openly and according to their needs' (emphasis added) [25]. Indeed, the first promise of the Policing Pledge, which all 43 forces in England and Wales have signed up to, states: 'We will always treat you fairly with dignity and respect ...' (emphasis added) [8]. Given these sentiments, it is legitimate to ask whether the powers to seize vehicles are exercised in a way that is fair.

It seems to us that Lisa was not treated fairly. She was deprived of her property though innocent of any crime. This caused her considerable inconvenience, distress and embarrassment. She felt that she had been mocked and dealt with in a dismissive way by the officers at the scene. No consideration seemed to have been given as to how she could most conveniently prove that her car was insured or to how she could easily reclaim her property. She suffered a significant financial loss. The way in which she was treated seems to fall short of the promise of Merseyside Police to treat everyone they deal with fairly, the sentiments expressed in the Policing Pledge, or with the Home Office's aspiration that the regulations should not unfairly penalise drivers.

It is notable that Lisa remained visibly distressed by the ordeal when interviewed by us two years after the event. She said that she had felt 'helpless', that she had been in a 'David and Goliath situation' and that she had 'never felt so small'.

\section{Conclusion}

Enforcing traffic laws even in democracies poses a particular challenge for public trust in police. It generates a high number of citizen contacts, including with citizens historically or socially otherwise disposed to support police, in situations in which strict enforcement is likely to leave citizens disgruntled if not handled carefully. [11; p.452].

Goldsmith's point, above, succinctly encapsulates the main thrust of our argument. In many cases in the UK, the only direct contact that members of the public have with the police is because of motoring offences, actual or potential. When processed erroneously, incorrectly, and with a lack of respect - as Lisa's case was - the result can be loss of trust and confidence in the police as a force for good. This, coupled with the lack of clarity regarding why motorists are charged a fee to reclaim their 
vehicles, not to mention how the fee is calculated, has led us to question the legitimacy of the police's actions. The public already display a degree of mistrust towards certain developments in police technology [31]; we suggest that phenomena we have discussed here will only exacerbate the situation.

There are a number of ways in which the police could operate their power of seizure in a fairer and more accountable way. First, forces should ensure that vehicles are seized only when there are reasonable grounds for believing that they have been driven unlawfully. Officers should be reminded not to unduly rely on the PNC/NID, that information contained there may be incorrect, and that absence from the Database does not give sufficient grounds to seize a vehicle. Second, we suggest that where a driver claims that they are driving lawfully officers should take reasonable steps to verify this or enable drivers to do so thereby allowing them to continue on their journey with minimal inconvenience. Third, it is questionable whether charging drivers to reclaim their vehicles is legitimate - particularly where they are innocent of any offence. If it was thought necessary, any costs incurred in dealing with unlawfully driven vehicles could be collected by the courts in the form of an enhanced fine after conviction. Where charges are made, we believe that those who are forced to pay them are made aware, or are able to discover, how they have been calculated. Fourth, each force should record how many seized vehicles are subsequently discovered to have been driven lawfully. This record should indicate the reasons for seizure. Without this, no assessment can be made of whether a particular force is exceeding its power or subjecting innocent drivers to a disproportionate, illegitimate burden. This, in turn, reduces the possibility of holding individual forces to account.

Taking into account Brodeur's [4] conceptualisation of high and low policing, we contend that Lisa's case, and others like it, are an example of the principal features of high policing being employed to deal with incidents normally the focus of low policing. As such, we suggest that existing structures of accountability are designed to manage public policing in its low form, not a form of public policing which is imbued with market principles and infiltrated by elements of high policing. If driving with(out) insurance is to be policed by the means discussed here, methods of holding the police to account when errors are made must adapt accordingly. 
Reference List

1. Alderson, J. (1979). Policing Freedom. Plymouth: Macdonald and Evans.

2. Bowling, B. (1999). The Rise and Fall of New York Murder: Zero Tolerance or Crack's Decline? British Journal of Criminology, 39(4), 531-554.

3. Britton, P. Insured driver's anger as police crush car. Manchester Evening. 6 February 2007. Available at http://www.manchestereveningnews.co.uk/news/s/235/235318 insured drivers anger_as_police_crush_car.html Accessed on 19 February 2010.

4. Brodeur, J. (2007). High and Low Policing in Post-9/11 Times. Policing: $A$ Journal of Policy and Practice, 1(1), 25-37.

5. Brown, S. (2007). The Meaning of Criminal Intelligence. International Journal of Police Science and Management, 9(4), 336-340.

6. Chan, J. (1999). Governing Police Practice: Limits of the New Accountability. British Journal of Sociology 50(2), 251-270.

7. Chan, J. (1997). Changing Police Culture: Policing in a Multicultural Society. Cambridge: Cambridge University Press.

8. Chan, J. (2003). Police and New Technologies. In Newburn, T. (Ed.), Handbook of Policing (pp. 655-679). Cullompton: Willan.

9. Corcoran, D. Merseyside Police. OSU Roads Policing - ANPR: Operation Tango - denying criminals the use of our roads. Available at http://www.merseyside.police.uk/index.aspx?articleid=1595. Accessed on 25 April 2010.

10. Directgov. The policing pledge. Available at http://www.direct.gov.uk/en/CrimeJusticeAndTheLaw/ThePolice/DG 181995 Accessed on 21 April 2010.

11. Ericson, R., \& Haggerty, K. (1997). Policing the Risk Society. Oxford: Clarendon.

12. Family's Hell in M-way Blunder. Manchester Evening News. 8 October 2008. Available at http://www.manchestereveningnews.co.uk/news/s/1071129 familys hell in mway_blunder. Accessed on 18 February 2010.

13. Goldsmith, A. (2005). Police Reform and the Problem of Trust. Theoretical Criminology 9(4), 443-470. 
14. Hinds, L. (2009). Public Satisfaction with Police: The Influence of General Attitudes and Police-Citizen Encounters. International Journal of Police Science and Management 11(1), 54-66.

15. Home Office. (2005). Explanatory Memorandum to the Road Traffic Act 1988 (Retention and Disposal of Seized Motor Vehicles) Regulations 2005/1606. London: HMSO.

16. Hudson, B. (2003). Justice in the Risk Society. London: Sage.

17. Ireland, S. (2005). Serious Organised Crime and Police Bill Parts 3-6 (not including cl. 124): Briefing for House of Lords Second Reading. London: JUSTICE.

18. Johnston, L. (1992). The Rebirth of Private Policing. London: Routledge.

19. Jones, T., \& Newburn, T. (1998). Private Security and Public Policing. Oxford: Oxford University Press.

20. Keane, N., \& Kleiven, M. (2009). Risky Intelligence. International Journal of Police Science and Management 11(3), 324-333.

21. Loader, I. (1999). Consumer Culture and the Commodification of Policing and Security. Sociology 33(2), 373-392.

22. Manning, P. (2001). Technology's Ways: Information Technology, Crime Analysis and the Rationalizing of Policing. Criminology and Criminal Justice 1(1), 83-103.

23. Manning, P. (2008). The Technology of Policing: Crime Mapping, Information Technology, and the Rationality of Crime Control. New York: NYU Press.

24. Manning, P. (1977). Police Work. Cambridge: MIT Press.

25. McGarry, J. Named, Shamed and Defamed by the Police. Forthcoming.

26. Merseyside Police. What can you expect? Our promises to you. Available at http://www.merseyside.police.uk/index.aspx?articleid=2303. Accessed on 29 March 2010.

27. Merseyside Police. (2009). Seizure and Retention of Motor Vehicles Uninsured or Driven by Unlicensed Drivers: Policy and Procedure.

28. Motor Insurers' Bureau. MID Faqs: Are there any rules about how quickly the data has to be loaded to the MID? Available at http://www.mib.org.uk/Motor+Insurance+Database/en/MID+Faqs/Rules+for+ speed + of + loading + data.htm. Accessed on 9 March 2010. 
29. Motor Insurers' Bureau. MID Faqs: Can the police legally seize my vehicle just because there's no record of my vehicle on the MID? Available at http://www.mib.org.uk/Motor+Insurance+Database/en/MID+Faqs/Can+my+v

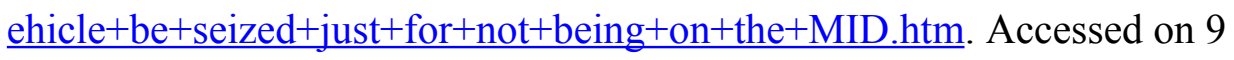
March 2010.

30. Motor Insurers' Bureau. Welcome to the Motor Insurers' Bureau. Available at http://www.mib.org.uk/Home/en/default.htm. Accessed on 11 March 2010.

31. Motor Insurers' Bureau. What is the MID? Available at http://www.mib.org.uk/Motor+Insurance+Database/en/Motor+Insurance+Data base+Information/What+is+the+MID.htm. Accessed on 9 March 2010.

32. Neyroud, P., \& Disley, E. (2008). Technology and Policing: Implications for Fairness and Legitimacy. Policing: A Journal of Policy and Practice 2(2), 226-232.

33. Parenti, C. (2009). Lockdown America: Police and Prisons in the Age of Crisis. London: Verson.

34. Rawlings, P. (2001). Policing: A short history. Cullompton: Willan.

35. Reiner, R. (1993). Police Accountability: Principles, Patterns and Practices. In Reiner, R., \& Spencer, S. (Eds.), Accountable Policing: Effectiveness, Empowerment and Equity (pp. 1-23). London: IPPR.

36. Road Traffic Act 1988.

37. Road Traffic Act 1988 (Retention and Disposal of Seized Motor Vehicles) (Amendment) Regulations 2008/2097.

38. Rowe, M. (2008). Introduction to Policing. London: Sage.

39. Royal Commission on the Police. (1962). Final Report. London: HMSO.

40. Serious Organised Crime and Police Act 2005.

41. Sheehy, P. (1993). Report of the Inquiry into Police Responsibilities and Rewards. London: HMSO.

42. Skogan, W. (2006). Asymmetry in the Impact of Encounters with Police. Policing \& Society 16(2), 99-126.

43. Skolnick, J. (1996). Justice without Trial. New York: Wiley.

44. Smith, D., \& Gray, J. (1985). Police and People in London: The PSI Report. Aldershot: Gower.

45. Tyler, T. (2004). Enhancing Police Legitimacy. The ANNALS of the American Academy of Political and Social Science, 593(1), 84-99. 
46. Wakefield, A. (2003). Selling Security: The Private Policing of Public Space. Cullompton: Willan.

47. Zedner, L. (2009). Security. Abingdon: Routledge.

48. Zedner, L. (2007). 'Pre-Crime and Post-Criminology? Theoretical Criminology 11(2), 261-281. 